\title{
EFFECT OF MINIRAL, ORGANIC AND BIO-FERTILIZERS COMBINATIONS ON GROWTH, YIELD COMPONENTS AND VOLATILE OIL OF Matricaria chamomilla PLANT
}

\author{
Mahmoud A.B. Ahmed, A.A.A. Meawad and M.A.I. Abdelkader* \\ Hort. Dept., Fac. Agric., Zagazig Univ., Egypt
}

Received: 25/08/2019 ; Accepted: 15/09/2019

\begin{abstract}
Two field experiments were carried out at a Private Farm named Royale herbs in Elbawiti Village, El Wahat El-Bharia District, Giza Governorate, Egypt during the two consecutive seasons of 2016/2017 and 2017/2018 to study the effect of different fertilizer types (mineral, organic and bio fertilizers) treatments on vegetative growth, yield components and volatile oil as well as total carbohydrates percentage of chamomile plant. The performance of organic fertilization (compost and humic acid) and biofertilization (nitobein or/and phosphorein) were compared with standard, commercial rates of $\mathrm{N}, \mathrm{P}, \mathrm{K}$ and $\mathrm{Mg}$ fertilizers with respect to the growth, yield and essential oil of Matricaria chamomilla. In the two successive seasons, plants treated with chemical fertilization showed a significant increase in vegetative growth (plant height, number of branches per plant, fresh and dry weights per plant) compared to the other types of fertilizers under study. The highest rate of chemical fertilizers $\left(\mathrm{N}, \mathrm{P}_{2} \mathrm{O}_{5}, \mathrm{~K}_{2} \mathrm{O}\right.$ and $\mathrm{MgO}$ at $125,100,62.5$ and $30 \mathrm{~kg}$ /faddan, respectively) recorded the highest value in each yield component (flower heads number per plant as well as flower heads air-dry weight per plant and per faddan) compared to the other ones under study, in most cases. In the same time, organic fertilization $\left(30 \mathrm{~m}^{3}\right.$ compost $+1 \mathrm{~kg}$ humic acid/ faddan) recorded an increase in these yield components compared to the other organic fertilizer rates in both seasons. Also, fertilization at ( $1 \mathrm{~kg}$ of nitrobein $+30 \mathrm{~m}^{3}$ compost/faddan) recorded a significant increase in volatile oil percentage of chamomile plant compared to either of sole chemical or biological fertilizer rates under study.
\end{abstract}

Key words: Matricaria chamomilla, chemical, organic and biological fertilizers, plant growth, flower heads yield, volatile oil.

\section{INTRODUCTION}

Chamomile (Matricaria chamomilla, L.) is an annual plant belongs to family Asteraceae. Chamomile is the most important medicinal plants worldwide. This plant has been used for thousands of years in traditional Roman, Greek and Egyptian medicine to treat different diseases such as anxiety, chest colds, psoriasis and insomnia (Andrzejewska and WoropajJanczak, 2014). Later, one third of human demands for drugs are acquired from medicinal and aromatic plants (Agatonovic-Kustrin et al., 2015). In addition, increasing demand of pharmaceutical factories for primary materials, more importantly, conservation of natural genetic resources and lay emphasis on the production as well as research on enhancing and processing of medicinal and aromatic plants.

The macronutrients, $\mathrm{N}, \mathrm{P}$, and $\mathrm{K}$, are often classified as 'primary' macronutrients, because deficiencies of $\mathrm{N}, \mathrm{P}$ and $\mathrm{K}$ are more common than the 'secondary' macronutrients, $\mathrm{Ca}, \mathrm{Mg}$, and S. Most of the macronutrients are represent 0.1 to $5 \%$, or 100 to 5000 parts per million (ppm), of dry plant tissue (Wiedenhoeft, 2006). Nitrogen is the most important nutrient element in terms of plant growth, physiology and carbohydrate content (Almodares et al., 2008).

\footnotetext{
*Corresponding author: Tel. : +201008002904

E-mail address: mohammedahmed1980@yahoo.com
} 
It is a constituent of chlorophyll, amino acids, proteins, alkaloids, and protoplasm. Phosphorus is an important constituent of bio-molecules like nucleic acids, phospholipids and ATP. Usually most soils are suffering from phosphorus deficient because of fixation problems, which makes it less available to the plants especially in clays soils (Gentili et al., 2006; Rotaru and Sinclair, 2009). Potassium is important for maintaining osmotic balance, phloem transport, and photosynthesis (Tripler et al., 2006). Moreover, improving nutrient use efficiency of crop plants leads to a substantial enhancement of the plant yields. Magnesium has major physiological and molecular roles in plants, such as being a component of the chlorophyll molecule, a co-factor for many enzymatic processes associated with phosphorylation, dephosphorylation. It has functions in protein synthesis that can affect the size, structure, and function of chloroplasts (Marschner, 1995).

Organic manure agriculture had become attention in the last few decades as a positive alternative to mineral fertilizers. Organic fertilizers are very save for human, animal and environment. It improves the soil properties, raising fertility of soil, reduce the costs and improve the quality of product and safe of pollution environment. Organic agriculture is based on minimizing the application of external inputs and avoiding the use of synthetic fertilizers and pesticides (Lazcano et al., 2009). Mikkelsen (2005) reported that humic acid has a high molecular weight and high complexation ability. Sangeetha et al. (2006) reported that humic material have two direct and indirect effects on physiological and biochemical processes in plant and on physical, chemical, and biological properties of soil.

Bio-fertilizers are complex of some microorganisms that mobilize main nutrients from unavailable to available one, could improve seed germination and root system, they are considered as a replacement for chemical fertilizers for improving soil fertility and crop production. Regarding the importance of medicinal plants and their role in human health, it is very important to increase their biomass without application of harmful chemical fertilizers. The most important advantages of growth promotion bacteria inducing was regulation hormones, development of growth and nutrients uptake (Mohamed, 2006).

The most important aim of this study was to investigate the effect of different fertilizer types (mineral, organic and bio-fertilizers) on growth, flower yield, volatile oil and total carbohydrates percentage of Matricaria chamomilla plant under Giza Governorate conditions.

\section{MATERIALS AND METHODS}

Two field experiments were carried out at Private Farm named Royale herbs in El-Bawiti Village, El-Wahat El-Baharia District, Giza Governorate, Egypt during the two consecutive seasons of $2016 / 2017$ and $2017 / 2018$, to study the effect of fertilizer types (mineral, organic and bio fertilizers) on vegetative growth, fruit yield components, volatile oil production and chemical constituents of chamomile (Matricaria chamomilla) plant.

Seeds of chamomile were obtained from Research Centre of Medicinal and Aromatic Plants, Hort. Res. Inst., ARC, Dokky, Giza, Egypt. The seeds were sown in the nursery on $15^{\text {th }}$ October, in the two seasons. The physical and chemical properties of the used soil were shown in Table 1, according to Chapman and Pratt (1978).

Chamomile transplants ( 30 days old about 10 $\mathrm{cm}$ lengths) were transplanted on $15^{\text {th }}$ November in both seasons. Seedlings were transplanted on one side of each ridge in $70 \mathrm{~cm}$ width and $30 \mathrm{~cm}$ apart. Each plot consists of three ridges; each one is $20 \mathrm{~m}$ long. The area of the experimental unit was $42 \mathrm{~m}^{2}$.

The current study was achieved to evaluate the effect of different fertilization types as follow:

\section{Mineral Fertilization}

Quantities of $\mathrm{N}+\mathrm{P}_{2} \mathrm{O}_{5}+\mathrm{K}_{2} \mathrm{O}+\mathrm{MgO}(\mathrm{kg} /$ fad.) were about:

1. $75+60+37.5+22.5$,

2. $100+80+50+30$ (recommended dose) and

3. $125+100+62.5+37.5$. 
Zagazig J. Agric. Res., Vol. 46 No. (6B) 2019

Table 1. Physical and chemical properties of experimental farm soil (average of two seasons)

\begin{tabular}{|c|c|c|c|c|c|c|c|c|c|c|}
\hline \multicolumn{8}{|c|}{ Mechanical analysis } & \multicolumn{3}{|c|}{ Soil texture } \\
\hline \multicolumn{2}{|r|}{ Clay (\%) } & \multicolumn{4}{|c|}{ Silt (\%) } & \multicolumn{2}{|r|}{ sand $(\%)$} & \multicolumn{3}{|c|}{ Sandy } \\
\hline \multicolumn{2}{|r|}{2.45} & \multicolumn{4}{|c|}{3.85} & \multicolumn{2}{|r|}{93.70} & & & \\
\hline \multicolumn{11}{|c|}{ Chemical analysis } \\
\hline \multirow[t]{2}{*}{ pH } & \multirow[t]{2}{*}{ E C m.mohs/cm } & \multicolumn{4}{|c|}{ Soluble cations (meq./l) } & \multicolumn{2}{|c|}{ Soluble anions (meq. / l) } & \multicolumn{3}{|c|}{ Available (ppm } \\
\hline & & $\mathrm{Mg}^{++}$ & $\mathrm{Ca}^{++}$ & $\mathbf{K}^{+}$ & $\mathrm{Na}^{+}$ & $\mathrm{Cl}^{-}$ & $\mathrm{HCO}_{3}^{-} \mathrm{SO}_{4}^{--}$ & $\mathbf{N}$ & $\mathbf{P}$ & $\mathbf{K}$ \\
\hline 7.80 & 0.77 & 2.5 & 3.5 & 1.3 & 0.8 & 1.5 & 5.0 & 0.04 & 8.30 & 0.2 \\
\hline
\end{tabular}

The chemical fertilizers were applied throw irrigation as ammonium sulfate $(20 \% \mathrm{~N})$, urea phosphate $\left(44 \% \mathrm{P}_{2} \mathrm{O}_{5}\right)$, potassium sulfate $(50 \%$ $\left.\mathrm{K}_{2} \mathrm{O}\right)$ and magnesium sulfate $(16 \% \mathrm{MgO})$ every three days intervals during the first and second seasons.

\section{Organic Fertilizers}

1. Compost at $30 \mathrm{~m}^{3} /$ faddan;

2. Compost at $30 \mathrm{~m}^{3}+1 \mathrm{~kg}$ humic acid/faddan;

3. Compost at $30 \mathrm{~m}^{3}+2 \mathrm{~kg}$ humic acid/faddan and

4. Compost at $30 \mathrm{~m}^{3}+3 \mathrm{~kg}$ humic acid/faddan.

Compost at $30 \mathrm{~m}^{3} /$ faddan was added at the time of soil preparation as a soil application. The moisture of compost was about $25-30 \%$. Also, physical and chemical properties of the used compost are shown in Table 2.

Vegetarian humic acid fertilizer (GrowTech For Agricultural Development Company) contains $92 \%$ humic acid. Humic acid rates were applied three times to the plant root area during the vegetative period starting 35 days intervals from planting time and between additions through drip irrigation system after being dissolved in fixed amount of irrigation water, when each addition.

\section{Organic and Bio-fertilizers}

1. Compost at $30 \mathrm{~m}^{3}+1 \mathrm{~kg}$ nitrobein/faddan;

2. Compost at $30 \mathrm{~m}^{3}+1 \mathrm{~kg}$ phosphorein/faddan and
3. Compost at $30 \mathrm{~m}^{3}+1 \mathrm{~kg}$ nitrobein $+1 \mathrm{~kg}$ phosphorein/faddan).

Chamomile seedlings were inoculated with nitrobein (Azospirillum lipofrum) and phosphorein (Bacillus megatherium var phosphaticum) just before transplanting and repeated again before flowering as soil application which produced by General Organization for Agriculture Equalization Fund (GOAEF).

The ten treatments were arranged in randomized complete block design with three replicates. The mineral fertilizer levels and humic acid rates treatments were added by using drip irrigation system (fertigation). All agricultural practices were performed as usual, in the region for the production of chamomile plants.

\section{Data Recorded}

A random sample of three plants from each sub plot was taken; the $1^{\text {st }}$ cut at 70 days and the $2^{\text {nd }}$ cut at 115 days after planting and the following data were recorded:

\section{Growth parameters}

After every cut, plant height $(\mathrm{cm})$, number of branches/plant as well as herb fresh and dry weights/plant (g) was recorded.

\section{Yield components}

After every cut, outside flower diameter $(\mathrm{cm})$, flower heads number/plant and flower heads air-dry weight/plant (g) and/faddan $(\mathrm{kg})$ were calculated. 
Table 2. Physical and chemical properties of the compost applied in the present study (average of two seasons)

\begin{tabular}{|c|c|c|c|c|c|c|c|c|c|}
\hline \multirow[t]{2}{*}{$\mathrm{pH}$} & \multirow{2}{*}{$\begin{array}{c}\text { E C } \\
\text { m.mohs/cm }\end{array}$} & \multirow{2}{*}{$\begin{array}{c}\text { Organic } \\
\text { matter }(\%)\end{array}$} & \multirow{2}{*}{$\begin{array}{c}\text { Organic } \\
\text { carbon (\%) }\end{array}$} & \multirow{2}{*}{$\begin{array}{l}\mathrm{C}: \mathrm{N} \\
\text { ratio }\end{array}$} & $\mathbf{M g}^{++}$ & $\mathrm{Ca}^{++}$ & $\mathbf{K}^{+}$ & $\mathrm{Na}^{+}$ & $\mathbf{P}$ \\
\hline & & & & & \multicolumn{5}{|c|}{$(p p m)$} \\
\hline 8.10 & 0.62 & 39.80 & 22.60 & $1: 14$ & 46.60 & 1405.10 & 476.20 & 644.00 & 4.30 \\
\hline
\end{tabular}

\section{Volatile oil and total carbohydrate percentages}

At harvest time (at the end of every cut) about $10 \mathrm{~g}$ of each air-dried sample (flower heads) was separated triturated and steam-hydro distilled for 3 hours. The extraction of oils was carried out according to method of European Pharmacopoeia (1983). Also, total carbohydrates percentage of flower heads was determined according to the methods described by AOAC (1990).

\section{Statistical Analysis}

Data of the present work were statically analyzed and the differences between the means of the treatments were considered significant when they were more than the least significant differences (LSD) at the 5\% level by using computer program of Statistix Version 9 (Analytical Software, 2008).

\section{RESULTS AND DISCUSSION}

\section{Growth Parameters}

The results illustrated in Table 3 show that, by general means assessment, the maximum increase in each of plant height and number of branches/plant values was obtained from the treatment of mineral fertilization compared to the other types (organic or bio fertilization) under study. There were no significant difference between organic and bio fertilization types in this concern, in most cases. However, $30 \mathrm{~m}^{3}$ compost $+1 \mathrm{~kg}$ nitrobein per faddan in the first season and $30 \mathrm{~m}^{3}$ compost $+1 \mathrm{~kg}$ nitrobein $+1 \mathrm{~kg}$ phosphorein per faddan in the second one gave the highest values regard number of branches/ plant compared to the other biofertilization rates under study.

Furthermore, fresh and dry weights of herb/ chamomile plant $(\mathrm{g})$ were gradually increased with increasing chemical fertilization rates in the two cuts during both seasons, in most cases (Table 4). Herb fresh and dry weights per plant were influenced by organic fertilizer treatments. The maximum values in this connection were obtained from combined application of $30 \mathrm{~m} 3$ compost/faddan and humic acid at $1 \mathrm{~kg} /$ faddan compared to the other organic fertilization rates in both seasons. In addition, chamomile herb fresh weight recorded the highest values in the first season and herb dry weight per plant in the two seasons by applied $30 \mathrm{~m}^{3}$ compost $+1 \mathrm{~kg}$ nitrobein $+1 \mathrm{~kg}$ phosphorein per faddan compared to the other biofertilization rates under study.

Moreover, in this respect El-Sherbeny et al. (2015) revealed that, in general, all NPK ratios caused significant stimulation to various growth parameters. Applied the ratio of 200:100:50 $\mathrm{kg} /$ fad., of NPK fertilizer produced the highest mean values of Portulaca oleracea characters (plant height, number of branches and fresh and dry weights).

In addition, El-Sayed $\boldsymbol{e t}$ al. (2018) showed that the organic fertilizers had a better effect on total herb fresh and dry weights per plant of Cymbopogon citratus than bio fertilizer treatments.

Also, Bio-fertilizer is microbial inoculants used for ferity with the objective of increasing the number of such microorganisms and to accelerate certain microbial processes in the rhizosphere of inoculated plants or soil to enhance plant growth and development (Willer and Lernoud, 2019). 
Table 3. Effect of mineral, organic and bio-fertilizers on plant height (cm) and number of branches per plant of Matricaria chamomilla during 2016/2017 and 2017/2018 seasons

\begin{tabular}{|c|c|c|c|c|c|c|c|c|}
\hline \multirow[t]{3}{*}{ Fertilization type } & \multicolumn{4}{|c|}{ Plant height (cm) } & \multicolumn{4}{|c|}{ Number of branches /plant } \\
\hline & \multicolumn{2}{|c|}{ First season } & \multicolumn{2}{|c|}{ Second season } & \multicolumn{2}{|c|}{ First season } & \multicolumn{2}{|c|}{ Second season } \\
\hline & $1^{\text {st }}$ cut & $2^{\text {nd }}$ cut & $1^{\text {st }}$ cut & $2^{\text {nd }}$ cut & $1^{\text {st }}$ cut & $2^{\text {nd }}$ cut & $\overline{1^{\text {st }} \text { cut }}$ & $2^{\text {nd }}$ cut \\
\hline N75 P60 K37.5 Mg18 & 68.67 & 86.67 & 55.13 & 60.50 & 18.33 & 20.33 & 15.00 & 18.00 \\
\hline N100 P80 K50 Mg24 & 68.67 & 88.33 & 51.70 & 57.03 & 20.00 & 22.00 & 12.00 & 17.00 \\
\hline N125 P100 K62.5 Mg30 & 73.00 & 87.00 & 51.77 & 59.30 & 20.33 & 22.33 & 14.33 & 16.33 \\
\hline General mean & 70.11 & 87.33 & $\mathbf{5 2 . 8 7}$ & 58.94 & 19.55 & 21.55 & 13.78 & 17.11 \\
\hline $30 \mathrm{~m}^{3}$ Compost & 53.00 & 67.33 & 47.63 & 53.63 & 16.00 & 18.00 & 16.33 & 16.33 \\
\hline $30 \mathrm{~m}^{3}$ Compost $+1 \mathrm{~kg}$ Humic acid & 58.33 & 71.33 & 52.13 & 57.90 & 15.33 & 17.33 & 15.33 & 17.00 \\
\hline $30 \mathrm{~m}^{3}$ Compost $+2 \mathrm{~kg}$ Humic acid & 61.67 & 78.00 & 54.50 & 59.50 & 14.67 & 16.67 & 16.00 & 17.33 \\
\hline $30 \mathrm{~m}^{3}$ Compost $+3 \mathrm{~kg}$ Humic acid & 54.00 & 71.33 & 45.77 & 51.53 & 15.67 & 17.67 & 16.33 & 15.33 \\
\hline General mean & 56.75 & 72.00 & 50.01 & 55.64 & 15.42 & 17.42 & 16.00 & 16.50 \\
\hline $30 \mathrm{~m}^{3}$ Compost + 1 kg Nitro & 54.67 & 70.00 & 53.03 & 60.13 & 14.67 & 16.67 & 15.00 & 16.33 \\
\hline $30 \mathrm{~m}^{3}$ Compost $+1 \mathrm{~kg}$ Phosph & 55.00 & 64.67 & 52.60 & 55.67 & 12.67 & 14.67 & 12.33 & 17.00 \\
\hline $30 \mathrm{~m}^{3}$ Compost $+1 \mathrm{~kg}$ Nitro $+1 \mathrm{~kg}$ phosph & 47.33 & 59.67 & 50.90 & 55.67 & 12.67 & 14.67 & 18.00 & 18.00 \\
\hline General mean & 52.33 & 64.78 & 52.18 & 57.16 & 13.33 & 15.34 & 15.11 & 17.11 \\
\hline LSD at 5\% & 12.73 & 9.41 & 2.53 & 2.38 & 2.71 & 2.70 & 4.03 & 4.75 \\
\hline
\end{tabular}

* Nitro $=$ Nitrobein and Phosph $=$ Phosphorein

Table 4. Effect of mineral, organic and bio-fertilizers on herb fresh and dry weights/plant (g) of Matricaria chamomilla during 2016/2017 and 2017/2018 seasons

\begin{tabular}{|c|c|c|c|c|c|c|c|c|}
\hline \multirow[t]{3}{*}{$\overline{\text { Fertilization type }}$} & \multicolumn{4}{|c|}{ Herb fresh weight/plant (g) } & \multicolumn{4}{|c|}{ Herb dry weight/ plant (g) } \\
\hline & \multicolumn{2}{|c|}{ First season } & \multicolumn{2}{|c|}{ Second season } & \multicolumn{2}{|c|}{ First season } & \multicolumn{2}{|c|}{ Second season } \\
\hline & $1^{\text {st }}$ cut & $2^{\text {nd }}$ cut & $1^{\text {st }}$ cut & $2^{\text {nd }}$ cut & $1^{\text {st cut }}$ & $\overline{2^{\text {nd }} \text { cut }}$ & $1^{\text {st }}$ cut & $\overline{2^{\text {nd }} \text { cut }}$ \\
\hline $\begin{array}{lll}\text { N75 } & \text { P60 K37.5 Mg18 }\end{array}$ & 101.00 & 118.67 & 228.50 & 304.00 & 22.96 & 25.11 & 51.50 & 63.82 \\
\hline N100 P80 K50 Mg24 & 89.33 & 105.33 & 269.00 & 357.67 & 19.35 & 21.66 & 58.00 & 75.15 \\
\hline N125 P100 K62.5 Mg30 & 99.17 & 116.67 & 294.25 & 391.33 & 24.20 & 26.99 & 72.00 & 91.45 \\
\hline General mean & 96.50 & 113.60 & 263.92 & 351.00 & 22.17 & 24.59 & 60.50 & 76.81 \\
\hline $30 \mathrm{~m}^{3}$ Compost & 88.47 & 104.00 & 97.50 & 129.67 & 24.82 & 27.07 & 28.50 & 35.27 \\
\hline $30 \mathrm{~m}^{3}$ Compost $+1 \mathrm{~kg}$ Humic acid & 80.17 & 94.33 & 149.50 & 199.00 & 17.72 & 19.10 & 33.25 & 42.27 \\
\hline $30 \mathrm{~m}^{3}$ Compost $+2 \mathrm{~kg}$ Humic acid & 91.33 & 107.67 & 169.00 & 224.67 & 20.53 & 22.89 & 40.75 & 51.09 \\
\hline $30 \mathrm{~m}^{3}$ Compost $+3 \mathrm{~kg}$ Humic acid & 118.33 & 139.33 & 171.00 & 227.00 & 29.13 & 32.30 & 42.00 & 52.45 \\
\hline General mean & 94.58 & 111.33 & 146.75 & 195.09 & 23.05 & 25.34 & 36.13 & 45.27 \\
\hline $30 \mathrm{~m}^{3}$ Compost $+1 \mathrm{~kg}$ Nitro & 48.00 & 56.00 & 204.00 & 271.33 & 11.18 & 11.55 & 46.00 & 53.55 \\
\hline $30 \mathrm{~m}^{3}$ Compost $+1 \mathrm{~kg}$ Phosph & 40.33 & 47.67 & 154.83 & 206.33 & 8.39 & 8.83 & 32.67 & 38.38 \\
\hline $30 \mathrm{~m}^{3}$ Compost $+1 \mathrm{~kg}$ Nitro $+1 \mathrm{~kg}$ phosph & 99.33 & 117.00 & 189.25 & 251.67 & 24.19 & 24.82 & 49.75 & 59.77 \\
\hline General mean & 62.55 & 73.56 & 182.25 & 243.11 & 14.58 & 15.07 & 42.81 & 50.57 \\
\hline LSD at $5 \%$ & 69.54 & 82.02 & 54.86 & 72.97 & 1.97 & 2.31 & 3.87 & 4.02 \\
\hline
\end{tabular}




\section{Yield Component Parameters}

According to results tabulated in Tables 5 and 6 it could be concluded that the chemical fertilizers progressively induced the highest number of flower heads /plant, flower heads airdry weight/plant and flower heads air-dry weight/faddan as compared with organic or biofertilization in both cuts and in the two seasons. Mostly, the highest values in this concern were obtained from $\mathrm{N}, \mathrm{P}_{2} \mathrm{O}_{5}, \mathrm{~K}_{2} \mathrm{O}$ and $\mathrm{MgO}$ at 125 , $100,62.5$ and $30 \mathrm{~kg} /$ faddan compared to the other ones in the two cuts during the two seasons under study. Moreover, the combination between $30 \mathrm{~m}^{3}$ compost $+3 \mathrm{~kg}$ humic acid/ faddan in the two cuts during the two seasons produced the highest values in outside flower diameter and number of flower heads/chamomile plant (except that of number of flower heads in the first one) compared to the other organic fertilization rates. However, flower heads air-dry weight/plant and/faddan in the first season recorded the highest values when treated with 30 $\mathrm{m}^{3}$ compost $+1 \mathrm{~kg}$ humic acid/faddan compared to $30 \mathrm{~m}^{3}$ compost alone. Generally, $30 \mathrm{~m}^{3}$ compost $+1 \mathrm{~kg}$ nitrobein gave the highest values in chamomile yield components (flower heads number per plant as well as flower heads air-dry weight per plant and per faddan) in the two cuts during both seasons, in most cases.

Furthermore, Nassar et al. (2015) revealed that increasing level of the used mineral fertilizers $(\mathrm{N}+\mathrm{P})$ induced significant increases in seed yield/plant of thorn apple plant. Seed yield of coriander was higher when 100\% fertilizer dose was used but yield decreased when 25\% less fertilizer applied (Kamrozzaman et al., 2016).

Also, El-Sayed et al. (2017) indicated that $100 \%$ organic fertilizer gave the highest dill number of umbels per plant, and umbel diameter. Meanwhile, 100\% organic fertilizer treatment was the best treatment for fruit weight (g/plant) and fruit yield (ton/fad.) compared with other treatments at the dried ripe fruits for two growing seasons. Almarie et al. (2019) proved the superiority of organic manure via enhancing yield components (number of umbels per plant, seed yield per plant and final seed yield per hectare) of caraway plants in comparing with no fertilizer.
In the same time, Marjoram transplant treated with halex-2 biofertilizers gave the highest values of herb fresh and dry yield, while plants treated with nitrobein as biofertilizers gave intermediate values at different cuts in this respect (Al-Fraihat et al., 2011). Arafa et al. (2017) reported that the treatment of farmyard manure + nitrobein was the most effective for increasing fresh and dry herb yields of Mentha longifolia, and the treatment of rabbit manure + nitrobein was the most effective for increasing the yield and main constituents of the volatile oil in both seasons. Baqual et al. (2019) concluded that the use of various forms and strains of nitrogen fixing bacteria viz., Azotobacter, Azospirrillum and Rhizobium has proven to be very promising in crop use either singly or in consortium which not only improves the yield but also holds a greater promise for effective control against various plant diseases. Moreover, Rahimi et al. (2019) showed that the highest seed yield and biological yield were observed in cephalaria plants treated with mycorrhiza + vermicompost, whereas the highest 1000 -seed weight was obtained from the application of mycorrhiza + manure.

\section{Volatile Oil and Total Carbohydrates}

Results shown in Table 7 indicate that, the percentage of chamomile volatile oil in flower heads was greatly increased by organic as well as bio-fertilizer treatment as it gave the highest values as compared to mineral fertilization at the both cuts in the two seasons. Whereas, the highest values in total carbohydrates percentage were obtained from $\mathrm{N}, \mathrm{P}_{2} \mathrm{O}_{5}, \mathrm{~K}_{2} \mathrm{O}$ and $\mathrm{MgO}$ at $100,80,50$ and $24 \mathrm{~kg}$ /faddan compared to the other ones in the two cut during the two seasons under study. General mean of biological fertilization produced the second highest values in this regard at the two cuts in both seasons. Matter and El Sayed (2015) found that NPK fertilizer led to improve plant total chlorophyll content which reflected on increasing essential oil (\%) of caraway plant.

Also, Aly et al. (2015) showed that total carbohydrate contents showed significant increase with applied nitrogen fertilizer treatments alone, meanwhile the total carbohydrate contents were increased insignificantly with the other used treatments during the two seasons in comparison 
Table 5. Effect of mineral, organic and bio-fertilizers on outside flower diameter (cm) and number of flower heads/plant of Matricaria chamomilla during 2016/2017 and 2017/ 2018 seasons

\begin{tabular}{|c|c|c|c|c|c|c|c|c|}
\hline \multirow[t]{3}{*}{ Fertilization type } & \multicolumn{4}{|c|}{ Outside flower diameter $(\mathrm{cm})$} & \multicolumn{4}{|c|}{ number of flower heads/ plant } \\
\hline & \multicolumn{2}{|c|}{ First season } & \multicolumn{2}{|c|}{ Second season } & \multicolumn{2}{|c|}{ First season } & \multicolumn{2}{|c|}{ Second season } \\
\hline & $1^{\text {st }}$ cut & $2^{\text {nd }}$ cut & $1^{\text {st }}$ cut & $2^{\text {nd }}$ cut & $1^{\text {st }}$ cut & $2^{\text {nd }}$ cut & $1^{\text {st }}$ cut & $2^{\text {nd }}$ cut \\
\hline $\begin{array}{ll}\text { N75 } & \text { P60 K37.5 Mg18 }\end{array}$ & 3.00 & 2.30 & 2.08 & 2.04 & 76.00 & 224.33 & 178.00 & 406.83 \\
\hline N100 P80 K50 Mg24 & 3.00 & 2.43 & 2.22 & 2.10 & 37.33 & 253.00 & 172.67 & 411.50 \\
\hline N125 P100 K62.5 Mg30 & 2.50 & 2.53 & 2.06 & 2.15 & 49.67 & 321.00 & 252.33 & 461.88 \\
\hline General mean & 2.83 & 2.42 & 2.12 & 2.10 & 54.33 & 266.11 & 201.00 & 426.74 \\
\hline $30 \mathrm{~m}^{3}$ Compost & 2.67 & 2.03 & 2.18 & 1.90 & 63.00 & 339.33 & 157.33 & 321.75 \\
\hline $30 \mathrm{~m}^{3}$ Compost $+1 \mathrm{~kg}$ Humic acid & 2.63 & 2.33 & 2.23 & 1.90 & 49.00 & 205.33 & 151.00 & 356.00 \\
\hline $30 \mathrm{~m}^{3}$ Compost $+2 \mathrm{~kg}$ Humic acid & 3.03 & 2.23 & 2.19 & 2.02 & 32.67 & 192.33 & 179.00 & 431.25 \\
\hline $30 \mathrm{~m}^{3}$ Compost $+3 \mathrm{~kg}$ Humic acid & 3.10 & 2.90 & 2.23 & 1.92 & 59.33 & 282.67 & 189.00 & 444.37 \\
\hline General mean & 2.86 & 2.37 & 2.21 & 1.94 & 51.00 & 254.92 & 169.08 & 388.34 \\
\hline $30 \mathrm{~m}^{3}$ Compost + 1 kg Nitro & 3.13 & 2.70 & 2.34 & 2.09 & 48.00 & 290.67 & 136.00 & 405.50 \\
\hline $30 \mathrm{~m}^{3}$ Compost + 1 kg Phosph & 3.20 & 2.53 & 2.12 & 2.07 & 22.67 & 142.00 & 96.00 & 367.08 \\
\hline $30 \mathrm{~m}^{3}$ Compost $+1 \mathrm{~kg}$ Nitro $+1 \mathrm{~kg}$ phosph & 2.76 & 2.27 & 2.28 & 2.08 & 34.00 & 227.67 & 169.67 & 395.00 \\
\hline General mean & 3.03 & 2.50 & 2.25 & 2.08 & 34.89 & 220.11 & 133.89 & 389.19 \\
\hline LSD at $5 \%$ & 0.63 & 0.64 & 0.21 & 0.15 & N.S. & 161.63 & $\mathbf{5 7 . 4 3}$ & $\mathbf{7 4 . 7 3}$ \\
\hline
\end{tabular}

* Nitro $=$ Nitrobein and Phosph $=$ Phosphorein.

Table 6. Effect of mineral, organic and bio-fertilizers on flower heads air-dry weight/ plant (g) and flower heads air-dry weight/faddan (kg) of Matricaria chamomilla during 2016/ 2017 and $2017 / 2018$ seasons

\begin{tabular}{|c|c|c|c|c|c|c|c|c|}
\hline \multirow[t]{3}{*}{ Fertilization type } & \multicolumn{4}{|c|}{$\begin{array}{l}\text { Flower heads air-dry } \\
\text { weight/ plant (g) }\end{array}$} & \multicolumn{4}{|c|}{$\begin{array}{c}\text { Flower heads air-dry } \\
\text { weight/ faddan (kg) }\end{array}$} \\
\hline & \multicolumn{2}{|c|}{ First season } & \multicolumn{2}{|c|}{ Second season } & \multicolumn{2}{|c|}{ First season } & \multicolumn{2}{|c|}{ Second season } \\
\hline & $1^{\text {st }}$ cut & $2^{\text {nd }}$ cut & $1^{\text {st }}$ cut & $2^{\text {nd }}$ cut & $1^{\text {st }}$ cut & $2^{\text {nd }}$ cut & $1^{\text {st }}$ cut & $2^{\text {nd }}$ cut \\
\hline $\begin{array}{lll}\text { N75 } & \text { P60 K37.5 Mg18 }\end{array}$ & 4.97 & 20.57 & 6.95 & 14.63 & 99.33 & 411.33 & 139.08 & 292.50 \\
\hline N100 P80 K50 Mg24 & 3.70 & 20.20 & 7.03 & 18.37 & 74.00 & 404.00 & 140.70 & 367.38 \\
\hline N125 P100 K62.5 Mg30 & 4.60 & 22.07 & 8.99 & 19.58 & 92.00 & 441.33 & 179.92 & 391.65 \\
\hline General mean & 4.42 & 20.95 & 7.66 & 17.53 & 88.44 & 418.89 & 153.23 & 350.51 \\
\hline $30 \mathrm{~m}^{3}$ Compost & 1.60 & 16.43 & 5.34 & 8.00 & 32.00 & 328.67 & 106.72 & 159.90 \\
\hline $30 \mathrm{~m}^{3}$ Compost $+1 \mathrm{~kg}$ Humic acid & 2.67 & 18.23 & 6.39 & 11.74 & 53.33 & 364.67 & 127.75 & 234.70 \\
\hline $30 \mathrm{~m}^{3}$ Compost $+2 \mathrm{~kg}$ Humic acid & 1.80 & 17.97 & 5.83 & 14.72 & 36.00 & 359.33 & 116.53 & 294.45 \\
\hline $30 \mathrm{~m}^{3}$ Compost $+3 \mathrm{~kg}$ Humic acid & 2.20 & 17.33 & 7.47 & 13.21 & 44.00 & 346.67 & 149.45 & 264.20 \\
\hline General mean & 2.07 & 17.49 & 6.26 & 11.92 & 41.33 & 349.83 & 125.11 & 238.31 \\
\hline $30 \mathrm{~m}^{3}$ Compost + $1 \mathrm{~kg}$ Nitro & 2.93 & 17.63 & 5.07 & 10.67 & 58.67 & 352.67 & 101.32 & 213.31 \\
\hline $30 \mathrm{~m}^{3}$ Compost $+1 \mathrm{~kg}$ Phosph & 2.20 & 15.67 & 3.03 & 11.78 & 44.00 & 313.33 & 60.53 & 235.61 \\
\hline $30 \mathrm{~m}^{3}$ Compost $+1 \mathrm{~kg}$ Nitro $+1 \mathrm{~kg}$ phosph & 1.87 & 14.03 & 4.97 & 13.14 & 37.33 & 280.67 & 99.34 & 262.85 \\
\hline General mean & 2.33 & 15.78 & 4.36 & 11.86 & 46.67 & 315.56 & 87.06 & 237.26 \\
\hline LSD at 5\% & 1.10 & 3.71 & 1.65 & 1.91 & 22.09 & 74.16 & 32.97 & 38.19 \\
\hline
\end{tabular}

* Nitro $=$ Nitrobein and Phosph $=$ Phosphorein 
Table 7. Effect of mineral, organic and bio-fertilizers on volatile oil and total carbohydrates percentages of Matricaria chamomilla during 2016/2017 and 2017 /2018 seasons

\begin{tabular}{|c|c|c|c|c|c|c|c|c|}
\hline \multirow[t]{3}{*}{ Fertilization type } & \multicolumn{4}{|c|}{ Volatile oil percentage } & \multicolumn{4}{|c|}{ Total carbohydrates percentage } \\
\hline & \multicolumn{2}{|c|}{ First season } & \multicolumn{2}{|c|}{ Second season } & \multicolumn{2}{|c|}{ First season } & \multicolumn{2}{|c|}{ Second season } \\
\hline & $1^{\text {st }}$ cut & $2^{\text {nd }}$ cut & $1^{\text {st }}$ cut & $2^{\text {nd }}$ cut & $1^{\text {st }}$ cut & $2^{\text {nd }}$ cut & $1^{\text {st }}$ cut & $2^{\text {nd }}$ cut \\
\hline N75 $\quad$ P60 K37.5 Mg18 & 0.87 & 0.95 & 0.88 & 0.94 & 16.50 & 17.05 & 17.24 & 17.11 \\
\hline N100 P80 K50 Mg24 & 0.71 & 0.78 & 0.76 & 0.82 & 18.47 & 19.05 & 18.37 & 19.52 \\
\hline N125 P100 K62.5 Mg30 & 0.78 & 0.85 & 0.83 & 0.89 & 17.28 & 17.82 & 17.39 & 18.04 \\
\hline General mean & 0.79 & 0.86 & 0.82 & 0.88 & 17.42 & 17.97 & 17.67 & 18.22 \\
\hline $30 \mathrm{~m}^{3}$ Compost & 0.93 & 1.02 & 0.96 & 1.02 & 15.30 & 15.44 & 15.17 & 15.40 \\
\hline $30 \mathrm{~m}^{3}$ Compost $+1 \mathrm{~kg}$ Humic acid & 1.39 & 1.49 & 1.35 & 1.41 & 15.38 & 15.54 & 15.42 & 15.61 \\
\hline $30 \mathrm{~m}^{3}$ Compost $+2 \mathrm{~kg}$ Humic acid & 1.23 & 1.32 & 1.22 & 1.29 & 15.58 & 15.76 & 15.47 & 16.13 \\
\hline $30 \mathrm{~m}^{3}$ Compost $+3 \mathrm{~kg}$ Humic acid & 1.10 & 1.18 & 1.08 & 1.14 & 16.09 & 16.25 & 15.75 & 16.23 \\
\hline General mean & 1.16 & 1.25 & 1.15 & 1.21 & 15.59 & 15.75 & 15.45 & 15.84 \\
\hline $30 \mathrm{~m}^{3}$ Compost $+1 \mathrm{~kg}$ Nitro & 1.17 & 1.24 & 1.15 & 1.20 & 16.37 & 15.85 & 15.27 & 16.16 \\
\hline $30 \mathrm{~m}^{3}$ Compost $+1 \mathrm{~kg}$ Phosph & 1.31 & 1.39 & 1.29 & 1.35 & 16.28 & 16.88 & 16.47 & 16.70 \\
\hline $\begin{array}{l}30 \mathrm{~m}^{3} \text { Compost }+1 \mathrm{~kg} \text { Nitro }+1 \mathrm{~kg} \\
\text { phosph }\end{array}$ & 1.00 & 1.09 & 1.03 & 1.03 & 17.09 & 17.39 & 16.83 & 17.55 \\
\hline General mean & 1.16 & 1.24 & 1.16 & 1.20 & 16.58 & 16.71 & 16.19 & 16.80 \\
\hline LSD at $5 \%$ & 0.005 & 0.006 & 0.006 & 0.007 & 0.36 & 0.50 & 0.44 & 0.40 \\
\hline
\end{tabular}

* Nitro $=$ Nitrobein and Phosph $=$ Phosphorein

with control plants content. Abdelkader et al. (2018) showed that the highest volatile oil (\%), volatile oil yield per plant and volatile oil yield per faddan were recorded as coriander plants were fertilized with $100 \%$ NPK rate compared to control. Meanwhile, Bajeli et al. (2016) showed that Japanese mint plants fertilized with organic manures recorded the highest values in volatile oil percentage compared to control. Regard biofertilization, Nejatzadeh-Barandozi and Pourmaleknejad (2014) found that fertilizing Thymus vulgaris plants with nitrobein gave a significant increase in oil production comparing to the control. Shirzadie et al. (2015) concluded that using mycorrhiza as well as azotobacter to fertilize basil plants led to an increase in the essential oil yield.

\section{Conclusion}

It is preferable from the previous results that treating chamomile plants with chemical fertilizers treatment, for enhancing growth and yield components of this plant. Therefore, the present study strongly admit the use of such treatment (organic and bio-fertilization) to provide good and high exportation characteristics due to its safety role on human health with increasing volatile oil percentage of Matricaria chamomilla.

\section{REFERENCES}

Abdelkader, M.A.I., A.S.H. Gendy, E.A. Bardisi and H.A. Elakkad (2018). The impact of NPK fertilization level and lithovit concentration on productivity and active ingredients of Coriandrum sativum plants. Middle East J. Appl. Sci., 8 (3): 827-836.

Agatonovic-Kustrin, S., D. Babazadeh Ortakand, D.W. Morton and A.P. Yusof (2015). Rapid evaluation and comparison of natural products and antioxidant activity in calendula, feverfew, and German chamomile extracts. J. Chromatogr. A, 1385: 103-10.

Al-Fraihat, A.H., S.Y.A. Al-dalain, Z.B. AlRawashdeh, M.S. Abu-Darwish and J.A. AlTabbal (2011). Effect of organic and biofertilizers on growth, herb yield and volatile oil of marjoram plant grown in Ajloun region, Jordan. J. Med. Plants Res., 13 (5): 2822-2833. 
Almarie, A.A., S.A.A. Al-Salmani and A.F. Almohammedi (2019). Response of caraway (Carum carvi L.) plants to organic manures in replacement of chemical fertilization. Res. J. Biotechnol., 14 (I): 283-288.

Almodares, A., R. Taheri, I. M. Chung and M. Fathi (2008). The effect of nitrogen and potassium fertilizers on growth parameters and carbohydrate contents of sweet sorghum cultivars. J. Environ. Biol., 29: 849-852.

Aly, M.S., A.N. El-Shahat, N.Y. Naguib, H.A. Said-Al Ahl, A.M. Zakaria and M.A. Abou Dahab (2015). Effect of nitrogen and/or biofertilizer on the yield, total flavonoids, carbohydrate contents, essential oil quantity and constituents of dill plants. Middle East J. Agric. Res., 4 (2): 291-296.

Analytical Software (2008). Statistix Version 9, Analytical Software, Tallahassee, Florida, USA.

Andrzejewska, J. and M. Woropaj-Janczak (2014). German chamomile performance after stubble catch crops and response to nitrogen fertilization. Ind. Crops Prod., 62: 350-358.

AOAC (1990). Official Methods of Analysis, $15^{\text {th }}$ Ed. Association of Official Analytical Chemists, Inc., Virginia, USA.

Arafa, A.M.S., A.M.Z. Sarhan, M.A. Mohamed and H.S. Abd Rabbu (2017). Effect of organic manures with biofertilizers on growth and volatile oil production of Mentha longifolia plant. Middle East J. Agric. Res., 6 (3): 748-756.

Bajeli, J., S. Tripathi, A. Kumar, A.Tripathi and R. K. Upadhyay (2016). Organic manures a convincing source for quality production of Japanese mint (Mentha arvensis L.). Industrial Crops and Prod., 83: 603-606.

Baqual, M.F., S. Farooq, A. Qayoom, S.A. Wani and H. Habib (2019). Use of nitrogen based bacterial biofertilisers on agricultural crop productivity. Int. J. Adv. Biol. Res., 9 (1): 1-8.

Chapman, D.H. and R.F. Pratt (1978). Methods of Analysis for Soils, Plants and Waters. Div. Agric. Sci., Univ. California USA, 16-38.

El-Sayed, A.A., A.S. El-Leithy, H.M. Swaefy and Z.F.M. Senossi (2018). Effect of NPK, bio and organic fertilizers on growth, herb yield, oil production and anatomical structure of (Cymbopogon citratus, Stapf) plant. Ann. Res. and Rev. Biol., 26 (2): 1-15.

El-Sayed, A.A., M.A. Darwish, S.N. Azoz, A.M. Abd-Alla and S.I.M. Elsayed (2017). Effect of mineral, bio and organic fertilizers on productivity, essential oil composition and fruit anatomy of two dill cultivars (Anethum graveolens L.). Mid. East J. Appl. Sci., 7 (3): 532- 550.

El-Sherbeny, S.E., S.S. El-Saadany, A.A. Youssef, R.A. El-Massry and S.A. El-Newary (2015). Response of Portulaca oleracea L. plants to various fertilizers ratios on growth, yield and chemical composition under Egyptian conditions. World J. Pharm. Sci., 3 (12): $2297-2307$.

European Pharmacopoeia (1983). Maissoneuve, SA: Sainte Ruffine, 1-8.

Gentili, F., L.G. Wall and K. Huss-Danell (2006). Effects of phosphorus and nitrogen on nodulation are seen already at the stage of early cortical cell divisions in Alnus incana. Ann. Bot., 98 : 309-315.

Kamrozzman, M.M., S. Ahmed and A.F.M.R. Quddus (2016). Effect of fertilizer on coriander seed production. Bangladesh $\mathrm{J}$. Agric. Res., 41 (2): 345-352.

Lazcano, C., J. Arnold, A. Tato, J.G. Zaller and J. Dominguez (2009). Compost and vermicompost as nursery pot components: effects on tomato plant growth and morphology. Spanish J Agric. Res., 7: 944-951.

Marschner, H. (1995). Mineral Nutrition of Higher Plants, $2^{\text {nd }}$ Ed., Academic Press Limited, Text Book.

Matter, F.M.A. and S.A.A. El-Sayed (2015). Influence of mixed NPK fertilizers with foliar spray of active dry yeast on caraway under newly reclaimed soil conditions. Middle East J. Appl. Sci., 5 (2): 423-430.

Mikkelsen, R.L. (2005). Humic materials for agriculture. Better Crops, 89 (3): 6-9.

Mohamed, F.E. (2006). Efficiency of biofertilizers organic and inorganic amendments on growth and essential oil of marjoram 
(Majornan hortensis) plant growth in sandy and calcareous soil. M.Sc. Thesis, Microbiol. Dept., Fac. Agric., Zagazig Univ., Egypt.

Nassar, R.M.A., M.S. Boghdady and D.A. Selim (2015). Effect of mineral and bio-fertilizers on vegetative growth, mineral status, seed yield, tropane alkaloids and leaf anatomy of thornapple plant (Datura stramonium L.). Middle East J. Agric. Res., 4 (4): 754-768.

Nejatzadeh-Barandozi, F. and B. Pourmaleknejad (2014). Effect of biological, organic and chemical fertilizers on vegetative growth, physiological characteristics and essential oils of (Thymus vulgaris L.). Ann. Res. and Rev. in Biol., 4(11): 1847-1853.

Rahimi, A., S.S. Moghaddam, M. Ghiyasi, S. Heydarzadeh, K. Ghazizadeh and J. Popovi'c-Djordjevi' (2019). The Influence of chemical, organic and biological fertilizers on agrobiological and antioxidant properties of Syrian cephalaria (Cephalaria Syriaca L.). Agric., 122 (9): 1- 13.

Rotaru, V. and T.R. Sinclair (2009). Interactive influence of phosphorus and iron on nitrogen fixation by soybean. Environ. and Exp. Bot., 66: 94-99.
Sangeetha, N., S. Palani and U. Ramar (2006). Effect of lignite humic acid and fertilizers on the yield of onion and nutrient availability. $18^{\text {th }}$ Word Cong. Soil Sci., Philadelphia, Pencilvania, USA.

Shirzadi, F., M.R. Ardakani, H. Asadirahmani and A. Asgari (2015). Effects of mycorrhiza (Glomus intraradices), azotobacter (Azotobacter chrocooccum) and vermicompost on yield and essential oil of basil (Ocimum basilicum L.) in organic agriculture. Int. J. Biosc., (IJB), 6 (7): 1-6.

Tripler, C.E., S.S. Kaushal, G.E. Likens and M.T. Walter (2006). Patterns in potassium dynamics in forest ecosystems. Ecol. Letters, 9: 451-466.

Wiedenhoeft, A.C. (2006). Plant Nutrition. Hopkins WG (eds) The Green World, Chelsea House publisher, New York NY, 1643.

Willer, H. and J. Lernoud (2019). The world of organic agriculture, statistics and emerging trends. Int. Federation of Organic Agric. Mov., (IFOAM): 27-35. 


\title{
تأثير توليفات من الأسمدة المعدنية والعضوية والحيوية على النمو والمساهمات المحصولية والزيت العطري لنبات شيح البابونج
}

\author{
محمود عبد الرؤف بغدادي أحمد ـ على عبد الحميد على معوض - محمد أحمد إبراهيم عبد القادر \\ قسم البساتين - كلية الزر اعة - جامعة الزقازيق - مصر
}

أجريت تجربتان حقليتان في مزرعة خاصة "تسمى رويال للأعشاب" بقرية الباويطي، منطقة الواحات البحرية،

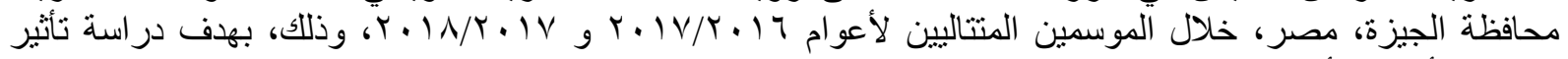

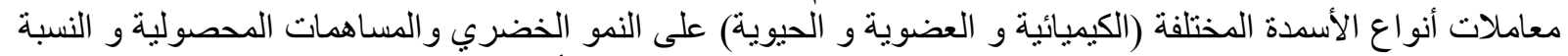

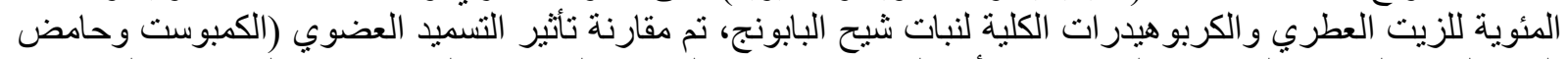

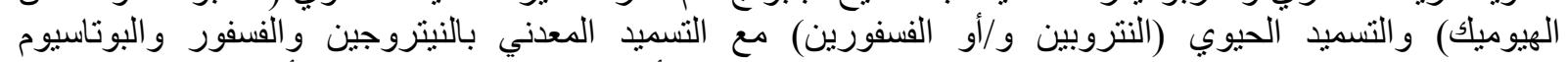

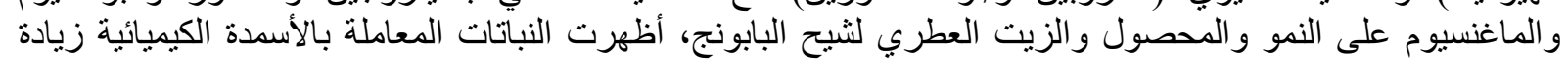

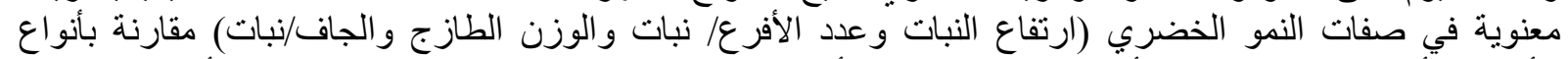

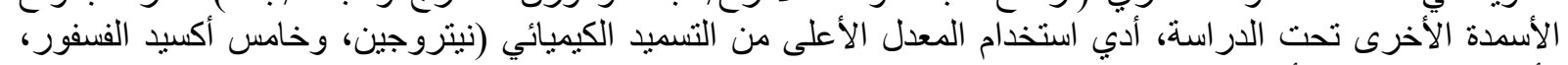

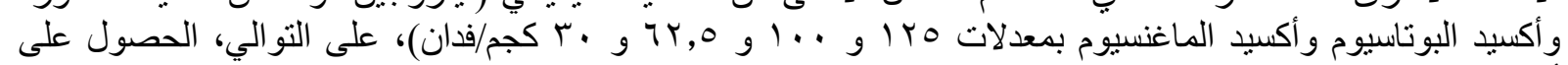

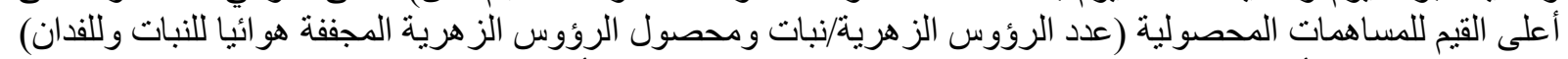

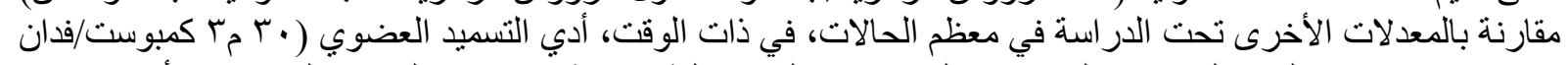

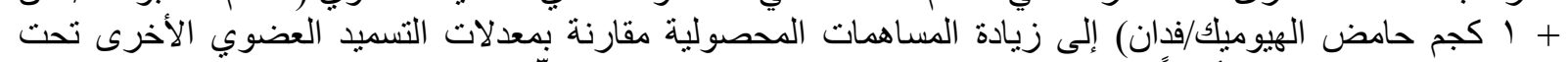

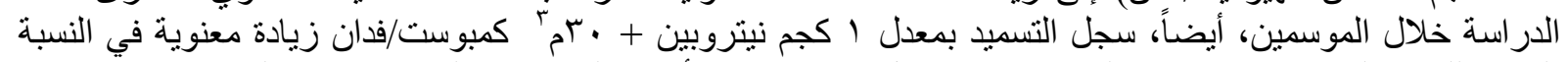

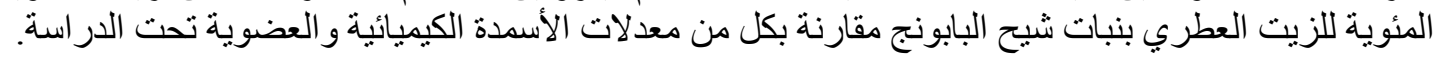

رئيس بحوث بقسم النباتات الطبية ـ مركز البحوث الزر اعية ـ الدقي ـ الجيزة.

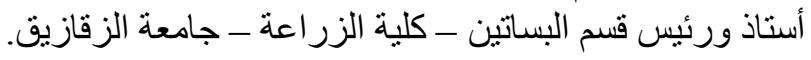

